\title{
Chemical dips and edible coatings to retard softening and browning of fresh-cut banana
}

\author{
Sheryl Lozel Sadili Bico, \\ Maria Filomena de Jesus Raposo, \\ Rui Manuel Santos Costa de Morais and \\ Alcina Maria Miranda Bernardo de Morais* \\ CBQF/Escola Superior de Biotecnologia, \\ Universidade Católica Portuguesa, \\ Rua Dr. António Bernardino de Almeida, \\ 4200-072 Porto, Portugal \\ E-mail: sheryllozel@yahoo.com \\ E-mail: fraposo@esb.ucp.pt \\ E-mail: rmmorais@esb.ucp.pt \\ E-mail: abmorais@esb.ucp.pt \\ *Corresponding author
}

\begin{abstract}
The effects of chemical dips and edible coatings on firmness and colour of fresh-cut banana (cv. Cavendish) from Madeira Island were investigated. Two calcium salts, calcium chloride and calcium lactate, were first investigated for the effects on firmness during four days of storage at $5^{\circ} \mathrm{C}$. Firmness and colour were evaluated after a three-minute chemical dipping or chemical dipping followed by coating and during five days of storage at $5^{\circ} \mathrm{C}$. The coatings tested consisted of pectin, alginate, carboxymethylcelullose, carrageenan or chitosan solution. Dip with $1 \%(\mathrm{w} / \mathrm{v})$ calcium chloride, $0.50 \%$ $(\mathrm{w} / \mathrm{v})$ ascorbic acid and $0.75 \%(\mathrm{w} / \mathrm{v})$ cysteine was the most efficient treatment in retarding softening and browning of banana slices. This dip also inhibited yeast growth. According to sensory analysis, the edible shelf life of banana slices dipped in such solution was the longest: five days at $5^{\circ} \mathrm{C}$. Carrageenan solution was the significantly $(\mathrm{p}<0.05)$ best coating among the ones studied, in preserving firmness and colour of fresh-cut banana during five days at $5^{\circ} \mathrm{C}$.
\end{abstract}

Keywords: fresh-cut banana; chemical dip; coating; firmness; colour.

Reference to this paper should be made as follows: Bico, S.L.S., de Jesus Raposo, M.F., de Morais, R.M.S.C. and de Morais, A.M.M.B. (2010) 'Chemical dips and edible coatings to retard softening and browning of fresh-cut banana', Int. J. Postharvest Technology and Innovation, Vol. 2, No. 1, pp.13-24.

Biographical notes: Sheryl Lozel S. Bico worked as a Master student at the Plant Biotechnology Laboratory from the Centre for Biotechnology and Fine Chemistry of the College of Biotechnology, from July 2007 to January 2008. She received her BSc in Chemistry in 2000 and her MSc in Agricultural Chemistry Minor in Food Science in 2007, from University of the Philippines Los Baños College, Laguna, Philippines and her MSc in Food Science, Technology and Nutrition (SEFOTECH.NUT) in 2008. She published one paper in a refereed international journal. She currently works in the Institute of Chemistry, University of the Philippines, Los Baños College, Laguna 4031, Philippines. 
Maria Filomena D.J. Raposo works currently as a Researcher at the Plant Biotechnology Laboratory from the Centre for Biotechnology and Fine Chemistry of the College of Biotechnology. She also teaches laboratory classes of several disciplines in the College, since 1998. She received her BSc in Biology from University of Aveiro, Portugal, in 1991 and her MSc in Applied Ecology from the University of Porto, Portugal, in 2005. She published five papers in refereed international journals. She also edited two chapters.

Rui Manuel S.C. de Morais currently holds an appointment as Coordinator of the Centre for Biotechnology and Fine Chemistry of the College of Biotechnology. He received his BSc in Pharmaceutical Sciences from the University of Porto, Portugal, in 1985 and his PhD in 1990 in Natural Sciences from the University of Saarland, Saarbruecken - Germany. In 1990, he became an Assistant Professor at the Portuguese Catholic University. He holds a position, presently, in the Directors Board of the European MSc in Food Science, Technology and Nutrition (SEFOTEC.NUT). He published papers in refereed international journals and he edited one book, as well as two chapters. He has two national patents.

Alcina Maria M. Bernardo de Morais currently holds an appointment as Coordinator of Food Engineering of the College of Biotechnology. She received her BSc in Chemical Engineering from University of Porto, Portugal, in 1985, her MSc, in 1986 and her PhD, in 1990, in Food Processing from Ecole Nationale Supérieure des Industries Agricoles et Alimentaires of Massy France. In 1990, she became an Assistant Professor at the Portuguese Catholic University at the College of Biotechnology. From 1999 to 2001, she held an appointment as Associate Sub-Director of the Extension of the College of Biotechnology in Caldas da Raínha. She published 37 papers in refereed international journals. Furthermore, she supervised funded research fellowships, including post-doc and successfully concluded $\mathrm{PhD}$ and MSc theses. She delivered invited lectures and volunteered presentations in professional meetings worldwide and has served in the organisation or scientific committees of national and international symposia.

\section{Introduction}

Over the years, different physical and chemical techniques have been developed to extend the shelf life of fresh-cut produce: refrigeration, disinfection (Hong and Gross, 1998), ethylene absorbers (Abe and Watada, 1991), gamma irradiation (Chervin and Boisseau, 1994), edible coating (Baldwin et al., 1995), chemical dipping (Vilas-Boas and Kader, 2006), controlled/modified atmosphere packaging (Brecht, 1999). Because different fruits react differently to different treatments, it is imperative that the right combination of these techniques is determined for each kind of fruit.

Texture and colour are two of the most noticeable quality parameters of fresh-cut fruits and vegetables that may change during storage. Application of calcium compounds (usually $1 \% \mathrm{CaCl}_{2}$ dips) helps to maintain the firmness of fresh-cut apple, pear, strawberry and banana (Vilas-Boas and Kader, 2006). The use of calcium chloride as firming agent, however, may impart bitterness or flavour differences (Olsen et al., 1966; Bolin and Huxsoll, 1989; Monsalve-Gonzalez et al., 1993). A residual amount of calcium chloride remains on the surface of the product after the dip treatment thus increasing the 
probability of bitterness detection by the consumer (Luna-Guzman and Barrett, 2000). The bitterness and salty taste caused by calcium chloride may be suppressed when calcium is combined with larger ions such as lactate, gluconate or glycerolphosphate (Lawless et al., 2003).

The thiol containing amino acid cysteine has been reported to effectively inhibit PPO-mediated enzymatic browning of fruit and vegetables (Joslyn and Ponting, 1951). Kahn (1985) reported that L-cysteine was shown to be the most effective inhibitor of browning in banana and avocado tissues.

Edible coatings have been used to preserve whole or fresh-cut produce since they may act as a barrier to water loss and oxygen access. The basic composition of edible coatings for fresh-cut fruits may include hydrocolloids and lipids. These hydrocolloids (proteins and carbohydrates) tend to form hydrophilic networks, usually being a good barrier to oxygen and carbon dioxide, but a poor barrier to water. Some polysaccharides that have been successfully used to coat fresh-cut fruits include carrageenan, maltodextrin, methylcellulose, carboxymethyl cellulose (CMC), pectin, alginate, chitosan, starch and microcrystalline cellulose (Debeaufort et al., 1998; Olivas et al., 2003; Pavlath et al., 1993; Rouse and Moore, 1972; Thommohaway et al., 2007; Wong et al., 1994).

The functional, nutritional, sensory and mechanical properties of the coating can be improved by the use of additives like anti-browning agents, preservatives, firming agents, plasticisers, nutraceuticals, volatile precursors, flavours and colours (Vojdani and Torres, 1990; Baldwin et al., 1996). Glycerol and polyethylene glycol (PEG) are the most often used plasticisers for cut fruits (Wong et al., 1994). These substances have the ability to modify the mechanical properties of the coatings by polymer chains, moving the chains apart and reducing the rigidity of the structures (Guilbert and Biquet, 1996).

Currently, there is little information about the combined effect of edible coatings and chemical dips on fresh-cut fruits. Moreover, only few research works have been conducted on fresh-cut banana and none was performed on banana from Madeira Island. Vilas-Boas and Kader (2006) studied the effect of combined effect of chemical dip and atmosphere composition on fresh-cut banana. Controlled atmosphere may be used as a hurdle technology for improvement of the protection against softening and browning of banana slices provided by carrageenan coating and chemical dip (Bico et al., 2009). Moline et al. (1999) proved that $0.5 \mathrm{M}$ citric acid and $0.05 \mathrm{M} \mathrm{N}$-acetylcysteine prevented browning at $5^{\circ} \mathrm{C}$ and $15^{\circ} \mathrm{C}$ during seven days.

Therefore, the objectives of this study were to maintain fresh-like quality (colour and firmness) of fresh-cut slices of 'Cavendish' banana from Madeira Island at $5^{\circ} \mathrm{C}$, by using chemical dips combined with edible coatings.

\section{Material and methods}

\subsection{Plant material}

Bananas (Musa acuminata Colla, cv. Cavendish) from Madeira Island at ripeness stage 4 (peel more yellow than green) and free of visible physical and fungal infection were purchased from the central market of Porto, Portugal (MAP). The bananas were 
transferred to the laboratory and were stored at $13 \pm 1{ }^{\circ} \mathrm{C}$ and $65 \%$ relative humidity (RH) until processing that happened within a week.

\subsection{Preparation of chemical dips}

The chemical dips used in the experiment were: $1 \%(\mathrm{w} / \mathrm{v})$ calcium chloride, $0.5 \%(\mathrm{w} / \mathrm{v})$ ascorbic acid and $0.75 \%(\mathrm{w} / \mathrm{v})$ cysteine, and $2 \%$ calcium lactate, $0.5 \%$ ascorbic acid and $0.75 \%$ cysteine.

Sterilised distilled water was used in the preparation of the chemical solutions to prevent from contamination with micro-organisms.

\subsection{Preparation of edible coatings}

\subsubsection{Alginate coating}

Alginate coating was prepared according to Rojas-Grau et al. (2007). Two grams of sodium alginate $\left(\mathrm{NaC}_{6} \mathrm{H}_{7} \mathrm{O}_{6}, \mathrm{BDH}\right.$, Poole, England) was dissolved in $100 \mathrm{ml}$ sterilised distilled water and heated at $70^{\circ} \mathrm{C}$, until the solution became clear. After cooling, glycerol $\left[\mathrm{C}_{3} \mathrm{H}_{5}(\mathrm{OH})_{3}, 85 \%\right.$ purity, Merck, Darmstadt, Germany] was added as plasticiser to a final concentration of $1.5 \mathrm{~g} / 100 \mathrm{ml}$ solution. The solution was emulsified with sunflower oil $(0.025 \mathrm{~g} / 100 \mathrm{ml}$ coating solution) at $24,500 \mathrm{rpm}$ for five minutes, before $\mathrm{pH}$ adjustment to 5.6 by using $50 \%$ (w/v) citric acid $\left(\mathrm{H}_{3} \mathrm{C}_{6} \mathrm{H}_{5} \mathrm{O}_{7}\right.$, Sigma Co., St. Louis, MO, USA).

\subsubsection{CMC coating}

CMC coating preparation was adapted from Lee et al. (2003). $0.20 \mathrm{~g} \mathrm{CMC} \mathrm{(CEKOL}$ 100,000 , CPKelco, Denmark) was dissolved in $50 \mathrm{ml}$ sterilised water. The solution was heated to $90^{\circ} \mathrm{C}$. A $50 \mathrm{ml}$ solution containing $0.08 \mathrm{~g}$ glycerol was added prior to stirring for 20 minutes. The $\mathrm{pH}$ was then adjusted to 5.6 by using $1.0 \mathrm{M} \mathrm{NaOH}$.

\subsubsection{Carrageenan coating}

Carrageenan coating was prepared according to Lee et al. (2003). $0.5 \mathrm{~g}$ carrageenan (GENEGEL CJ, CPKelco, Denmark) was dissolved in $100 \mathrm{ml}$ sterilised distilled water. A 50:50 (w/w) mixture of glycerol and PEG 4000 (Merck, Darmstadt, Germany) was used as plasticiser $(0.75 \mathrm{~g} / \mathrm{g}$ carrageenan $)$. The solution was equilibrated at $70^{\circ} \mathrm{C}$ and stirred vigorously with a magnetic stirrer bar for 40 minutes, on a hot plate. The solution was cooled down to room temperature prior to $\mathrm{pH}$ adjustment (5.6) by using $50 \%$ citric acid.

\subsubsection{Chitosan coating}

Chitosan coating was prepared according to Vargas et al. (2006). One gram of chitosan $(1 \% \mathrm{w} / \mathrm{v})$ (Sigma Aldrich, Switzerland) was dispersed in an aqueous solution of glacial acetic acid $(1 \% \mathrm{v} / \mathrm{v})$ at $40^{\circ} \mathrm{C}$. Tween 80 at $0.1 \%$ was added to improve wettability. After eight hours of stirring, olive oil was added to chitosan solution to a final concentration of $2 \%(\mathrm{v} / \mathrm{v})$. The mixture was emulsified by stirring for four minutes before adjusting the $\mathrm{pH}$ to 5.6 by using $1.0 \mathrm{M} \mathrm{NaOH}$. 


\subsubsection{Pectin coating}

Pectin coating preparation was adapted from Maftoonazad et al. (2007). A $0.5 \%$ (w/w) pectin solution was prepared by rehydrating pectin (GENU LM-104 AS-FS, CPKelco, Denmark) in sterilised distilled water $\left(12\right.$ hours at $\left.20^{\circ} \mathrm{C}\right)$ and $0.05 \%(\mathrm{w} / \mathrm{v})$ of sorbitol (Sigma Co., St. Louis, MO, USA). The mixture was homogenised with magnetic stirring until it became clear. Then $0.05 \%(\mathrm{w} / \mathrm{v})$ melted beeswax was added and emulsified by using a homogeniser at $14,000 \mathrm{rpm}$ for four minutes, prior to $\mathrm{pH}$ adjustment (5.6) by using 1.0 M sodium hydroxide ( $\mathrm{NaOH}$, Sigma Co., St. Louis, MO, USA).

\subsection{Sample preparation}

Bananas were washed with running water, dipped into chlorinated water $(0.75 \%$ active chlorine) for five minutes and room temperature forced air-dried. The banana was then peeled and sliced $(1 \mathrm{~cm}$ thickness) with a sharp sterilised knife in a laminar flow chamber. Ten similar slices were taken from each banana. Three replicates of ten slices from different bananas per treatment and per day were analysed for the effect of chemical dipping and/or edible coating. The samples were placed in an ice bath immediately after cutting.

Two different treatments were used:

1 dip alone

2 dip + coating.

In the two treatments, banana slices were dipped into the chemical solution for three minutes. The excess solution was allowed to drip off the banana slices surface for five minutes on tissue paper, and stored in $250 \mathrm{ml}$ opened plastic containers. In treatment 2 , chemically dipped bananas were coated with a specific solution, and the excess solution was drip off the surface of the slices for one minute, before storage in the plastic containers. All samples were stored at $5^{\circ} \mathrm{C}$ and $55 \% \mathrm{RH}$.

Slices dipped in distilled water were used as control. The temperature of the chemical dips and the distilled water used were maintained at $5^{\circ} \mathrm{C}$ while the coating solution, previously stored at $20^{\circ} \mathrm{C}$, was kept at room temperature.

\subsection{Firmness evaluation}

Firmness of each slice was determined with a Texture Analyzer Plus (TA-XT, Stable Micro Systems, UK) by measuring the force required for a $2 \mathrm{~mm}$ probe to penetrate $10 \mathrm{~mm}$ into the cut surface. Each slice was punctured thrice in each opposite side. A load of $20 \mathrm{~N}$ was used. Maximum force was registered. Firmness determinations were performed in triplicate. Ten slices per replicate were used for the analysis.

\subsection{Colour evaluation}

Colour on opposite sides of each slice was measured with a hand-help trismulus reflectance colourimeter (Minolta CR-300, Minolta Corporation, Ramsey, NJ) in the CIE $L^{*} a * b *$ mode CIELAB colour space (CIE, 1978). Chroma (C) was calculated by using 
the formula $\mathrm{C}=\left(\mathrm{a}^{*^{2}}+\mathrm{b}^{*^{2}}\right)^{1 / 2}$. Colour determinations were performed in triplicate. Ten slices per replicate were used.

\subsection{Sensory analysis}

Sensory evaluation was performed by 20 trained panelists, after five days of storage at $5^{\circ} \mathrm{C}$, on samples that had been dipped in $1 \%(\mathrm{w} / \mathrm{v})$ calcium chloride $\left(\mathrm{CaCl}_{2}\right), 0.50 \%(\mathrm{w} / \mathrm{v})$ ascorbic acid and $0.75 \%(\mathrm{w} / \mathrm{v})$ cysteine or dipped in this solution and coated with carrageenan solution. The parameters evaluated were global appreciation, colour, odour, texture and flavour. The following scale was used for scoring these attributes: 1 , very bad; 3 , neither good nor bad, 5, very good.

\subsection{Statistical analysis}

The SPSS 11.5 for Windows (Chicago, Illinois, USA) was used for the analysis of data. Statistical significance was assessed by one-way analysis of variance. The overall least significance difference (LSD; $p=0.05$ ) was calculated and used to detect significant differences among storage times. Relationships among measurement variables were studied by using the correlation factor (R).

\section{Results and discussion}

\subsection{Effects of calcium salt in chemical dips}

The first part of this research dealt with the selection of the chemical dip solution that can reduce softening and browning rates of banana slices. The firming agent, calcium ion, and some antioxidants (ascorbic acid and cysteine) composed the chemical dips. To determine the effect of two salts (calcium chloride and calcium lactate) on firmness of banana slices, the same calcium concentration $(0.09 \mathrm{~mol} \mathrm{Ca} / \mathrm{L})$ was used in the dipping solutions with also the same amount of ascorbic acid $(0.50 \%)$ and cysteine $(0.75 \%)$.

Untreated banana slices (control) had firmness loss of $52 \%$ (from $0.97 \mathrm{~N}$ to $0.47 \mathrm{~N}$ ) after four days of storage at $5^{\circ} \mathrm{C}$. Both chemically dipped samples were significantly firmer than water dipped one (control) from the second day of storage, but no difference was observed between the effects of dip with calcium chloride and dip with calcium lactate during storage. At the end of storage (four days) they presented $0.71 \mathrm{~N}$ and $0.69 \mathrm{~N}$, respectively. Luna-Guzman and Barrett (2000) reported that a similar or better tissue firming effect was observed when using $2.5 \%$ calcium chloride or $2.5 \%$ calcium lactate than water dip on fresh-cut cantaloupe. Agar et al. (1999) reduced the softening of kiwifruit slices by dipping into $0.5 \%$ or $1 \%$ calcium chloride, or $0.5 \%$ calcium lactate.

However, pinking was observed in samples treated with dip with calcium lactate. This may be an indicator of yeast growth. In fact, microbiological analysis carried out in the Microbiology Laboratory of the Associação para a Escola Superior de Biotecnologia da Universidade Católica (AESBUC), Porto, Portugal, identified the yeast Cryptococcus humiculus in samples treated with calcium lactate after two days of storage. Difference in $\mathrm{pH}$ (dip 1 and dip 2 have $\mathrm{pH}$ values of 2.80 and 4.30, respectively) and source of calcium salts may have triggered the growth of the yeast. Mountney and Gould (1988) reported that yeasts and moulds can grow in $\mathrm{pH}$ range of 4 to 4.5 . 
Richard et al. (1991) found that when cysteine is used as inhibitor of enzymatic browning, pinkish-red coloured compounds may be formed due to phenol regeneration with deep colour formation. Vilas-Boas and Kader (2006) reported that pinking occurs in banana slices if cysteine concentration is less that $0.5 \%$. A 2 min dip in a mixture of $1 \%(\mathrm{w} / \mathrm{v}) \mathrm{CaCl}_{2}+1 \%(\mathrm{w} / \mathrm{v})$ ascorbic acid $+0.5 \%(\mathrm{w} / \mathrm{v})$ cysteine effectively prevented browning and softening of banana slices for six days at $5^{\circ} \mathrm{C}$. Dips in cysteine with concentrations between 0.5 to $1.0 \%$ delayed browning and extended the post-cutting life to seven days at $5^{\circ} \mathrm{C}$. Furthermore, fresh-cut banana treated with chemical dip $\mathrm{pH} 2.5$ showed a longer shelf life than $\mathrm{pH} 7.0$, in terms of firmness. This is in contrast with Gorny et al. (2002) who found that a mixture of $2 \%(\mathrm{w} / \mathrm{v})$ ascorbic acid $+1 \%(\mathrm{w} / \mathrm{v})$ calcium lactate $+0.5 \%(\mathrm{w} / \mathrm{v})$ cysteine at $\mathrm{pH} 7$ was more effective in preventing softening of fresh-cut pears than the same mixture at $\mathrm{pH} 3.7$.

Calcium chloride was chosen to be the calcium salt used in the chemical dip of subsequent experiments because calcium lactate promoted yeast growth.

\subsection{Effects of chemical dip and/or coating on firmness}

Firmness was chosen as the quality indicator parameter for the study of the effects of chemical dip and/or coating. Since the effect of storage on firmness of fresh-cut banana was pronounced during the first two days in the previous experiment with the two calcium salts, the study of the effect of edible coating with or without chemical dip on firmness of banana slices was shortened to three days of storage at $5^{\circ} \mathrm{C}$ (Table 1).

Table 1 Effects of different chemical dips and edible coatings on firmness of fresh-cut banana after three days of storage at $5^{\circ} \mathrm{C}$

\begin{tabular}{lccccc}
\hline \multirow{2}{*}{ Treatment } & \multicolumn{5}{c}{ Firmness } \\
\cline { 2 - 6 } & Day 0 & & Day 3 & & Relative decrease, \% \\
\hline Control & $0.64 \pm 0.09$ & $\mathrm{~b}$ & $0.35 \pm 0.04$ & $\mathrm{e}$ & 47 \\
Dip & $0.69 \pm 0.09$ & $\mathrm{a}$ & $0.46 \pm 0.04$ & $\mathrm{c}$ & 32 \\
Alginate & $0.64 \pm 0.10$ & $\mathrm{~b}$ & $0.53 \pm 0.05$ & $\mathrm{~b}$ & 22 \\
Dip + alginate & $0.66 \pm 0.09$ & $\mathrm{a}$ & $0.56 \pm 0.04$ & $\mathrm{ab}$ & 16 \\
CMC & $0.67 \pm 0.10$ & $\mathrm{ab}$ & $0.39 \pm 0.04$ & $\mathrm{de}$ & 42 \\
Dip + CMC & $0.68 \pm 0.10$ & $\mathrm{ab}$ & $0.52 \pm 0.04$ & $\mathrm{~b}$ & 22 \\
Carrageenan & $0.67 \pm 0.09$ & $\mathrm{ab}$ & $0.41 \pm 0.04$ & $\mathrm{~d}$ & 40 \\
Dip + carrageenan & $0.67 \pm 0.08$ & $\mathrm{ab}$ & $0.57 \pm 0.06$ & $\mathrm{a}$ & 15 \\
Chitosan & $0.64 \pm 0.09$ & $\mathrm{~b}$ & $0.46 \pm 0.05$ & $\mathrm{c}$ & 31 \\
Dip + chitosan & $0.65 \pm 0.09$ & $\mathrm{~b}$ & $0.51 \pm 0.04$ & $\mathrm{~b}$ & 24 \\
Pectin & $0.68 \pm 0.07$ & $\mathrm{ab}$ & $0.40 \pm 0.03$ & $\mathrm{~d}$ & 41 \\
Dip+ pectin & $0.70 \pm 0.10$ & $\mathrm{a}$ & $0.53 \pm 0.05$ & $\mathrm{~b}$ & 22 \\
\hline
\end{tabular}

Notes: Dip contains $1 \%$ calcium chloride, $0.5 \%$ ascorbic acid and $0.75 \%$ cysteine. CMC is carboxymethyl cellulose. Different letters in the same column means significantly different $(p<0.05)$.

The loss of firmness in control sample was around $47 \%$, whilst firmness of dipped + coated samples decreased by $15-24 \%$ (Table 1 ). Among the treated samples, coating with $\mathrm{CMC}$, carrageenan and pectin solutions produced the highest relative decrease of firmness $(\sim 40 \%)$, while dip alone showed $32 \%$ of relative decrease. 
The combined effect of the chemical dip $\left(1 \% \mathrm{CaCl}_{2}, 0.5 \%\right.$ ascorbic acid and $0.75 \%$ cysteine) and coating, especially with alginate and carrageenan solutions (firmness loss of $\sim 15 \%$ ), reduced the softening rate compared to the untreated (control), dipped alone and only coated samples.

\subsection{Combined effect of chemical dip and coating on firmness and colour}

Since coating alone, in general, did not provide protection against firmness losses, another experiment was carried out with dip and dip combined with coating, and the study was extended to five days storage, and it included colour since it is also a critical quality parameter, along with texture. Although dip + chitosan, revealed a good protection against firmness losses (Table 1), it was not further investigated because of poor pre-sensorial analysis (bitter taste).

Table 2 shows that firmness of untreated banana slices decreased significantly during five days of storage, showing a substantial softening of 54\%. Among all treatments, dip alone and dip + carrageenan showed the lowest firmness loss ( $47 \%)$ while dip + pectin was found to have the highest relative decrease (64\%).

Table 2 Firmness $(\mathrm{N})$ and $\mathrm{L}^{*}$ and chroma values of chemically dipped and coated fresh-cut banana during five days of storage at $5^{\circ} \mathrm{C}$

\begin{tabular}{|c|c|c|c|c|c|c|}
\hline \multirow{2}{*}{ Treatment } & Day 0 & & & & Day 5 & \\
\hline & \multicolumn{6}{|c|}{ Firmness (N) } \\
\hline Control & $1.13 \pm 0.09$ & $\mathrm{a}$ & $0.69 \pm 0.06$ & $\mathrm{c}$ & $0.51 \pm 0.05$ & $\mathrm{c}$ \\
\hline Dip & $1.15 \pm 0.10$ & $\mathrm{a}$ & $0.78 \pm 0.08$ & $\mathrm{a}$ & $0.60 \pm 0.06$ & a \\
\hline Dip + alginate & $1.10 \pm 0.11$ & $\mathrm{a}$ & $0.73 \pm 0.07$ & $\mathrm{~b}$ & $0.55 \pm 0.05$ & $\mathrm{~b}$ \\
\hline Dip + CMC & $1.09 \pm 0.10$ & a & $0.57 \pm 0.05$ & $\mathrm{~d}$ & $0.47 \pm 0.04$ & $\mathrm{~d}$ \\
\hline Dip + carrageenan & $1.11 \pm 0.10$ & $\mathrm{a}$ & $0.75 \pm 0.07$ & $a b$ & $0.58 \pm 0.06$ & $\mathrm{a}$ \\
\hline \multirow[t]{2}{*}{ Dip + pectin } & $1.12 \pm 0.11$ & $\mathrm{a}$ & $0.68 \pm 0.05$ & $\mathrm{c}$ & $0.40 \pm 0.04$ & $\mathrm{e}$ \\
\hline & \multicolumn{6}{|c|}{$L^{*}$ value } \\
\hline Control & $69.6 \pm 2.0$ & $\mathrm{a}$ & $52.2 \pm 2.7$ & $\mathrm{~d}$ & $51.4 \pm 2.3$ & $\mathrm{c}$ \\
\hline Dip & $70.8 \pm 2.6$ & $\mathrm{a}$ & $68.7 \pm 1.5$ & $\mathrm{a}$ & $60.6 \pm 3.4$ & $\mathrm{a}$ \\
\hline Dip + alginate & $68.8 \pm 2.7$ & a & $61.7 \pm 2.1$ & $\mathrm{~b}$ & $49.6 \pm 2.8$ & $\mathrm{c}$ \\
\hline Dip+ CMC & $70.6 \pm 0.8$ & a & $56.6 \pm 2.8$ & $\mathrm{c}$ & $49.6 \pm 2.8$ & $\mathrm{c}$ \\
\hline Dip + carrageenan & $70.1 \pm 1.1$ & $\mathrm{a}$ & $56.3 \pm 3.3$ & $\mathrm{c}$ & $53.1 \pm 3.4$ & $\mathrm{~b}$ \\
\hline \multirow[t]{2}{*}{ Dip + pectin } & $70.0 \pm 0.8$ & $\mathrm{a}$ & $61.6 \pm 2.0$ & $\mathrm{~b}$ & $47.4 \pm 2.6$ & $\mathrm{c}$ \\
\hline & \multicolumn{6}{|c|}{ Chroma } \\
\hline Control & $39.5 \pm 1.7$ & $\mathrm{a}$ & $32.7 \pm 1.4$ & $\mathrm{c}$ & $30.8 \pm 2.1$ & $\mathrm{~b}$ \\
\hline Dip & $40.6 \pm 1.4$ & $\mathrm{a}$ & $36.7 \pm 1.3$ & $\mathrm{a}$ & $34.7 \pm 2.1$ & $\mathrm{a}$ \\
\hline Dip + alginate & $39.5 \pm 2.0$ & a & $34.8 \pm 2.4$ & $\mathrm{~b}$ & $27.1 \pm 4.0$ & $\mathrm{~b}$ \\
\hline $\mathrm{Dip}+\mathrm{CMC}$ & $40.3 \pm 0.7$ & a & $33.6 \pm 3.0$ & bc & $27.5 \pm 3.6$ & $\mathrm{c}$ \\
\hline Dip + carrageenan & $40.1 \pm 1.5$ & $\mathrm{a}$ & $33.2 \pm 2.7$ & $\mathrm{c}$ & $29.7 \pm 2.4$ & $\mathrm{~b}$ \\
\hline Dip $1+$ pectin & $39.8 \pm 1.6$ & $\mathrm{a}$ & $36.3 \pm 2.3$ & $\mathrm{a}$ & $28.3 \pm 3.8$ & $\mathrm{c}$ \\
\hline
\end{tabular}

Notes: Dip contains $1 \%$ calcium chloride, $0.5 \%$ ascorbic acid and $0.75 \%$ cysteine. CMC is carboxymethyl cellulose. Different letters in the same column means significantly different $(p<0.05)$. 
Calcium dip makes fruit tissue firmer by reacting with pectic acid in the cell wall to form calcium pectate that strengthens molecular binding between cell wall constituents (King Jr. and Bolin, 1989). Lee et al. (2003) found that edible coating such as carrageenan and whey protein isolate, together with calcium chloride and some other antibrowning agents, can minimise softening of apple slices.

The effect of dip and dip + coating in inhibiting browning was evaluated by monitoring the changes in $\mathrm{L}^{*}$ and chroma $(\mathrm{C})$ values during storage (Table 2). Vilas-Boas and Kader (2006) and Abe et al. (1998) evaluated browning of banana pulp by monitoring the decrease of $\mathrm{L}^{*}$ values, while Rocha and Morais (2001) used $\mathrm{L}^{*}$ and $\mathrm{C}$ (along with $\mathrm{a}^{*}, \mathrm{~b}^{*}$ and hue) values to evaluate browning in apples during storage. Lower $\mathrm{L}^{*}$ and $\mathrm{C}$ values indicate greater browning.

Compared to the control, all five treatments resulted in significantly reduced rates of browning after two days of storage. Dip treated samples showed the highest $\mathrm{L}^{*}$ and $\mathrm{C}$ during all storage. At the end of storage (five days), they were followed by dip + carrageenan treatment.

Addition of antioxidants such as ascorbic acid, cysteine and 4-hexylresorsinol to coatings like whey protein concentrate-beeswax and carrageenan may reduce browning in fresh-cut apples (Baldwin et al., 1996; Lee et al., 2003; Perez-Gago et al., 2003). On the other hand, Baldwin et al. (1996) reported that CMC based coating did not control enzymatic browning of cut apples and potatoes; but when such coating was combined with additives such as antioxidants, acidulants and preservatives, browning became inferior to the control.

Although chemical dip associated with carrageenan coating can decrease the rate of softening and browning of fresh-cut banana, dip alone had a better efficiency in reducing browning.

\subsection{Sensory analysis}

The sample that had been dipped in $1 \%$ calcium chloride, $0.50 \%$ ascorbic acid and $0.75 \%$ cysteine received the highest score for colour after five days of storage at $5^{\circ} \mathrm{C}$ (Table 3 ). This sample also received better score than the one that had been dipped in the same solution and coated with carrageenan solution for global appreciation and flavour after the same period. However, the highest score obtained was not very high: 3.34.

The sensory results indicated that, taking into account all sensory parameters evaluated, the dipped sample was the only one with edible shelf life of five days at $5^{\circ} \mathrm{C}$ if the limit of acceptability is set at 3.0.

Table 3 Sensory evaluation of chemically dipped and carrageenan coated fresh-cut banana after five days of storage at $5^{\circ} \mathrm{C}$

\begin{tabular}{lccccc}
\hline Treatment & $\begin{array}{c}\text { Global } \\
\text { appreciation }\end{array}$ & Colour & Odour & Texture & Flavour \\
\hline Control & $2.73 \pm 0.84 \mathrm{ab}$ & $2.17 \pm 0.86 \mathrm{~b}$ & $3.07 \pm 0.91 \mathrm{a}$ & $2.85 \pm 0.92 \mathrm{a}$ & $2.88 \pm 1.12 \mathrm{ab}$ \\
Dip & $3.21 \pm 1.13 \mathrm{a}$ & $3.01 \pm 0.99 \mathrm{a}$ & $3.23 \pm 1.24 \mathrm{a}$ & $3.23 \pm 1.05 \mathrm{a}$ & $3.34 \pm 1.17 \mathrm{a}$ \\
Dip+ carrageenan & $2.57 \pm 0.81 \mathrm{~b}$ & $2.29 \pm 0.87 \mathrm{~b}$ & $2.69 \pm 0.93 \mathrm{ab}$ & $2.66 \pm 0.92 \mathrm{ab}$ & $2.53 \pm 0.96 \mathrm{~b}$ \\
\hline
\end{tabular}

Notes: Dip contains $1 \%$ calcium chloride, $0.5 \%$ ascorbic acid and $0.75 \%$ cysteine. Different letters in the same column means significantly different $(p<0.05)$. 


\section{Conclusions}

The combined effect of chemical dips and/or edible coatings on fresh-cut banana was investigated.

Dip containing 1\%(w/v) calcium chloride $\left(\mathrm{CaCl}_{2}\right), 0.50 \%(\mathrm{w} / \mathrm{v})$ ascorbic acid and $0.75 \%(\mathrm{w} / \mathrm{v})$ cysteine and dip containing $2 \%(\mathrm{w} / \mathrm{v})$ calcium lactate, $0.50 \%(\mathrm{w} / \mathrm{v})$ ascorbic acid and $0.75 \%(\mathrm{w} / \mathrm{v})$ cysteine were found to have same firming effect on fresh-cut banana during four days of storage at $5^{\circ} \mathrm{C}$. However, the latter dip solution was found to cause pinking and yeast growth. Compared with dip with calcium chloride + coating, control and coating alone, in general, presented higher rates of browning and softening after three days storage. Carrageenan solution revealed itself the best coating, among the ones studied, in preserving firmness and colour of fresh-cut banana during five days at $5^{\circ} \mathrm{C}$. Dip with $1 \%(\mathrm{w} / \mathrm{v}) \mathrm{CaCl}_{2}, 0.50 \%(\mathrm{w} / \mathrm{v})$ ascorbic acid and $0.75 \%(\mathrm{w} / \mathrm{v})$ cysteine was the most efficient treatment in retarding softening and browning of this produce. According to sensory analysis, the edible shelf life of banana slices dipped in such solution was the longest: five days at $5^{\circ} \mathrm{C}$.

\section{Acknowledgements}

The authors acknowledge financial support from project SEFOTECH.NUT (Erasmus Mundus programme 28027-IC-6-2001-BE-ERASMUS-EPS-1). The authors thank CPKelco for offering the CMC, carrageenan and pectin.

\section{References}

Abe, K. and Watada, A.E. (1991) 'Ethylene absorbent to maintain quality of lightly processed fruits and vegetables', Journal of Food Science, Vol. 56, pp.1589-1592.

Abe, K., Tanase, M. and Chachin, K. (1998) 'Studies on physiological and chemical changes of fresh-cut banana (part I) efffect of cutting modes on the changes of physiological activity and deterioration in fresh-cut green tip bananas', Journal of Japanese Society of Horticultural Science, Vol. 67, pp.123-129.

Agar, I., Massantini, R., Hess-Pierce, B. and Kader, A.A. (1999) 'Postharvest $\mathrm{CO}_{2}$ and ethylene production and quality maintenance of fresh-cut kiwifruit slices', Journal of Food Science, Vol. 64, pp.433-440.

Baldwin, E.A., Nisperos, M.O., Chen, X. and Hagenmaier, R.D. (1996) 'Improving storage life of cut apple and potato with edible coating', Postharvest Biology and Technology, Vol. 9, pp.151-163.

Baldwin, E.A., Nisperos-Carriedo, M.O. and Baker, R.A. (1995) 'Use of edible coatings to preserve quality of lightly (and slightly) processed products', Critical Reviews in Food Science and Nutrition, Vol. 35, pp.509-552.

Bico, S.L.S., Raposo, M.F.J., Morais, R.M.S.C. and Morais, A.M.M.B. (2009) 'Combined effects of chemical dip and/or carrageenan coating and/or controlled atmosphere on quality of fresh-cut banana', Food Control, Vol. 20, pp.508-514.

Bolin, H.R. and Huxsoll, C.C. (1989) 'Storage stability of minimally processed fruit', Journal of Food Processing and Preservation, Vol. 13, pp.281-292.

Brecht, J.K. (1999) 'Postharvest quality and safety in fresh-cut vegetables and fruits', Cooperative Regional Research Project S-294. 
Chervin, C. and Boisseau, P.P. (1994) 'Quality maintenance of 'ready-to-eat' shredded carrots by gamma irradiation', Journal of Food Science, Vol. 59, pp.359-361.

Commission Internationale de L'Eclairage (CIE 1978) 'Recommendations on uniform colour spaces - colour-difference equations, psychometric colour terms', CIE. Publ. 15, Suppl. 2, Paris.

Debeaufort, F., Quezada-Gallo, J.Á and Voilley, A. (1998) 'Edible films and coatings: tomorrow's packaging: a review', Critical Reviews in Food Science, Vol. 38, pp.299-313.

Gorny, J.R., Hess-Pierce, B., Cifuentes, R.A. and Kader, A.A. (2002) 'Quality changes in fresh-cut pear slices as affected by controlled atmosphere and chemical preservatives', Postharvest Biology and Technology, Vol. 24, pp.271-278.

Guilbert, S. and Biquet, B. (1996) 'Edible films and coatings', in Bureau, G. and Multon, J.L. (Eds.): Food Packaging Technology, pp.315-347, VCH Publishers Inc., New York.

Hong, J.H. and Gross, K.C. (1998) 'Surface sterilization of whole tomato fruit with sodium hypochlorite influences subsequent postharvest behavior of fresh-cut slices', Postharvest Biology and Technology, Vol. 13, pp.51-58.

Joslyn, M.A. and Ponting, J.D. (1951) 'Enzyme-catalyzed oxidative browning of fruit products', Advanced Food Research, Vol. 3, p.44.

Kahn, V. (1985) 'Effects of proteins, protein hydrolyzates, and amino acids on $o$-dihydroxyphenolase activity of polyphenol oxidase of mushroom, avocado and banana', Journal of Food Science, Vol. 50, pp.111-115.

King Jr., A.D. and Bolin, H.R. (1989) 'Physiological and microbiological storage stability of minimally processed fruits and vegetables', Food Technology, Vol. 42, pp.132-135, 139.

Lawless, H.T., Rapack, F., Horne, J. and Hayes, A. (2003) 'The taste of calcium and magnesium salts and anionic modifications', Food Quality and Preference, Vol. 14, pp.319-325.

Lee, J.Y., Park, H.J., Lee, C.Y. and Choi, W.Y. (2003) 'Extending shelf-life of minimally processed apples with edible coatings and antibrowning agents', Lebensmittel-Wissenschaft und-Technologie, Vol. 36, pp.323-329.

Luna-Guzman, I. and Barrett, D.M. (2000) 'Comparison of calcium chloride and calcium lactate effectiveness in maintaining shelf stability and quality of fresh-cut cantaloupes', Postharvest Biology and Technology, Vol. 19, pp.61-72.

Maftoonazad, N., Ramaswamy, H.S., Moalemiyan, M. and Kushalappa, A.C. (2007) 'Effect of pectin-based edible coating on changes in quality if avocado exposed to Lasiodiplodia theobromae infection', Carbohydrate Polymers, Vol. 68, pp.341-349.

Moline, H.E., Buta, J.G. and Newman, I.M. (1999) 'Prevention of browning of banana slices using natural products and their derivatives', Journal of Food Quality, Vol. 22, pp.499-511.

Monsalve-Gonzalez, A., Barbosa-Cánovas, G.V. and Cavalieri, R.P. (1993) 'Mass transfer and textural changes during processing of apples by combined methods', Journal of Food Science, Vol. 58, pp.1118-1124.

Mountney, G.J. and Gould, W.A. (1988) Practical Food Microbiology and Technology, p.351, AVI Books, New York, Van Nostrand Reinhold Company.

Olivas, G.I., Rodriguez, J.J. and Barbosa-Cánovas, G.V. (2003) 'Edible coatings composed of methylcellulose stearic acid and additives to preserve quality of pear wedges', Journal of Food Processing and Preservation, Vol. 27, pp.299-320.

Olsen, R.W., Barron, R.W., Huggart, R.L. and Wenzel, F.W. (1966) 'Effect of calcium salts on the firmness of canned grapefruit sections', Proceedings of the Florida State Horticultural Society, Vol. 79, pp.326.

Pavlath, A.E., Wong, D.S.W. and Kumosinski, T.F. (1993) 'New coating for cut fruits and vegetables', Chem. Tech2., pp.36-40.

Perez-Gago, M.B., Serra, M., Alonso, M., Mateos, M. and del Rio M.A. (2003) 'Effect of solid content and lipid content of whey protein isolate-beeswax edible coatings on colour change of fresh-cut apples', Journal of Food Science, Vol. 68, pp.2186-2191. 
Richard, F.C., Goupy, P.M., Nicolas, J.J., Lacombe, J.M. and Pavia, A.A. (1991) 'Cysteine as an inhibitor of enzymatic browning'. 1. Isolation and characterization of addition compounds formed during oxidation of phenolics by apple polyphenol oxidase', Journal of Agricultural Food Chemistry, Vol. 39, pp.841-847.

Rocha, A.M.C.N. and Morais, A.M.M.B. (2001) 'Polyphenoloxidase activity and total phenolic content as related to browning of minimally processed 'Jonagored' apple', Journal of the Science of Food and Agriculture, Vol. 82, pp.120-126.

Rojas-Grau, M.A., Tapia, M.S., Carmona, A.J. and Martin-Belloso, O. (2007) 'Alginate and gellan-based edible coatings as carriers of antibrowning agents applied on fresh-cut Fuji apples', Food Hydrocolloid, Vol. 27, pp.118-127.

Rouse, A.H. and Moore, E.L. (1972) 'All-purpose gel blend for preparing citrus gels', Proceedings of the Florida State Horticultural Society, Vol. 79, pp.229-232.

Thommohaway, C., Uthairatanakij, A., Kanlayanarat, S. and Jitareerat, P. (2007) 'Quality of fresh-cut guava (Psidium guajava L.) as affected by chitosan treatment', Acta Horticulturae, Vol. 746, pp.449-454.

Vargas, M., Albors, A., Chiralt, A. and Gonzalez-Martinez, C. (2006) 'Quality of cold-stored strawberries as affected by chitosan-oleic acid edible coatings', Postharvest Biology and Technology, Vol. 41, pp.164-171.

Vilas-Boas, E.V. and Kader, A.A. (2006) 'Effect of atmospheric modification, 1-MCP and chemicals on quality of fresh-cut banana', Postharvest Biology and Technology, Vol. 39, pp.155-162.

Vojdani, F. and Torres, A. (1990) 'Potassium sorbate permeability of methylcellulose and hydroxypropyl methylcellulose coatings: effect of fatty acids', Journal of Food Science, Vol. 55, pp.841-846.

Wong, D.W.S., Tillin, S.J., Hudson, J.S. and Pavlath, A.E. (1994) 'Gas exchange in cut apples with bilayer coatings', Journal of Agricultural Food Chemistry, Vol. 42, pp.2278-2285. 